\title{
Soil Fertility Status and Productivity Trends Along a Toposequence: A Case of Gilgel Gibe Catchment in Nadda Assendabo Watershed, Southwest Ethiopia
}

\author{
Siraj Beshir ${ }^{1, ~ *, ~ M u l u g e t a ~ L e m e n e h ~}{ }^{2}$, Endalkachew Kissi ${ }^{3}$ \\ ${ }^{1}$ Madawalabu University, Department of Plant Science, Bale Robe, Ethiopia \\ ${ }^{2}$ International Livestock Research Institute (ILRI), Addis Ababa, Ethiopia \\ ${ }^{3}$ Jimma University, Department of Natural Resource Management, Jimma, Ethiopia
}

Email address:

siraj.beshir@mwu.edu.et (S. Beshir)

\section{To cite this article:}

Siraj Beshir, Mulugeta Lemeneh, Endalkachew Kissi. Soil Fertility Status and Productivity Trends Along a Toposequence: A Case of Gilgel Gibe Catchment in Nadda Assendabo Watershed, Southwest Ethiopia. International Journal of Environmental Protection and Policy.

Vol. 3, No. 5, 2015, pp. 137-144. doi: 10.11648/j.ijepp.20150305.14

\begin{abstract}
The Impact of landscape positions and land use type on properties as well as land productivity are commonly observed in Ethiopia. The study was therefore conducted to quantify soil fertility and productivity trends under three land uses along the gradient (lower, middle and upper slope positions) of Nadda Assendabo watershed, Southwest Ethiopia. Thus field survey was covered a total of 54 composite soil samples using split plots (for soil physical properties) and split-split factorial arrangements with randomized complete block design from woodlot, grazing and crop land following topographic positions then different parameters were analyzed. The highest mean soil moisture content $(56.68 \%)$ and porosity $(71.09 \%)$ were observed for woodlot at the lower slope while the highest soil bulk density $\left(1.74 \mathrm{~g} / \mathrm{cm}^{3}\right)$ was observed for soil crop land at the upper slope where as the lowest $\left(0.94 \mathrm{~g} / \mathrm{cm}^{3}\right)$ was for woodlot at the lower slope. Sand, silt and clay fractions were significantly affected by interaction effects of slope and land uses $(\mathrm{P} \leq 0.01)$. Soil $\mathrm{pH}$, electrical conductivity, organic carbon, cation exchange capacity, total nitrogen, available phosphorus, base saturation percentage and exchangeable basic cations for all land uses were increased down slope while they were affected significantly by slope steepness, land use and soil depth $(\mathrm{P} \leq 0.01)$. Therefore, electrical conductivity at middle and upper slope in grazing land and woodlot; total nitrogen, available phosphorus in crop land at lower slope was significantly different $(\mathrm{P} \leq 0.05)$ due to interaction effect. Furthermore, above ground biomass and grain yields of sorghum, maize and teff were also calculated on farm fields using split plots arrangements. Thus both yields were significantly affected by interaction effect of slope and crop type. Finally, based on the results woodlot, grazing and crop land were recommended for upper, middle and lower slopes respectively.
\end{abstract}

Keywords: Toposequence, Biomass and Grain Yield, Productivity Indicators

\section{Introduction}

Land is an essential resource particularly for agrarian society like Ethiopia. It is also a scarce resource with a carrying capacity that can be stretched only to a limited extent with the help of technology. As population grows rapidly, imbalance between supply for land resource and demand for it emerges. The consequences of imbalanced relationship are brought about either by natural or human factors such as deforestation, land degradation, soil erosion and conflict over land uses as a result of limited care of the resources and lack of awareness of the long-term effects (Buzuayehu et al., 2002). Some of the conservation measures like terracing, bunds and counter cultivation could be used for sustaining land productivity (Desta, 2003). In addition, small holder farmers use woodlot as means for reducing soil loss and resolving boundary conflict that may be raised due to land fragmentation into patch (Chris et al., 2004). The trees planted for this purpose could be used for construction, fuel wood and reducing pressure on utilizing crop residues (Bezuayehu et al., 2002).

A decline in soil fertility is becoming one of the major challenges for establishing sustainable agriculture in sub Saharan African countries (Muchena, 2008) This is enhanced by changes in land use, alteration of the ecosystem and susceptibility of the land to external pressure which 
significantly affect soil physical, chemical, and biological properties. Due to these trends agricultural productivity per unit of land is declining through time and food production could not keep pace with population growth (Roy et al., 2003).

Mostly, soil fertility parameters are influenced by rugged topography, steep slopes and land mosaic which results in exacerbating soil erosion rate through its morphological characteristics (Azene, 1997; Demel, 2001). On sloping lands, more than one-half of the soil particles that are dislodged by raindrops during rainfall are carried downhill (Brubaker et al., 1993; Brady and Weil, 2002). Erosion increases dramatically because the increased angle facilitates water flow and soil movement. It is generally accepted that an increase in slope will increase soil erosion by water and landslide because they lead to an increase in overland flow volume and velocity. Runoff on lower slopes flows slowly and forms a water layer quickly deep enough to act as surface mulch (Wischmeier and Smith, 1978).

Beside, Ethiopia is a country where more than $85 \%$ of its labour force is engaged in agriculture (CSA, 2010). So working in the agriculture sector to improve the level of its productivity is a key issue to meet the requirements of the continued population growth. According to (FAO, 2010, as cited in Taffesse, 2011), the country population density per land area was 82.95 people per square kilometer and this resulted in the fragmentation of land into patch dynamics, which influences nutrient flow and further land productivity.
In sight of this, Southwestern Ethiopia has a strong potential for increased agricultural productivity due to high intense of woodlot which its tree species has less allellopathic effect on fragmented landscape (JZARDS, 2011). However, environmental challenges, mainly deforestation and the consequential soil erosion and nutrient depletion, have profound effects, and threatened the livelihoods of the farmers.

Poor land management practices coupled with the rugged topography, erosive rainfall and more intense of gully and rill formation in Omo Nadda Woreda (Mainly Nadda Assendabo watershed) affected the agricultural practices in the area (SLMP, 2010). As a consequence, an increase in sediment load in down slope and reduction of agricultural productivity is becoming a challenge for small holder farmers. Some research have been done in the study area covered the area of land use/land cover dynamics and its impact (Amanuel, 2011); comparative analysis of soil nutrient balance at farm level (Abebayehu et al., 2011) reported that land use change and absence of nutrient balance brought low soil productivity. However, no study has been done on the land use planning, soil fertility and land productivity following the gradients. Therefore, the objective of this study was designed to investigate impact of topographic position and land use on soil fertility and its productivity in Omo Nadda woreda specifically Nadda Assendabo watershed, Southwest Ethiopia.

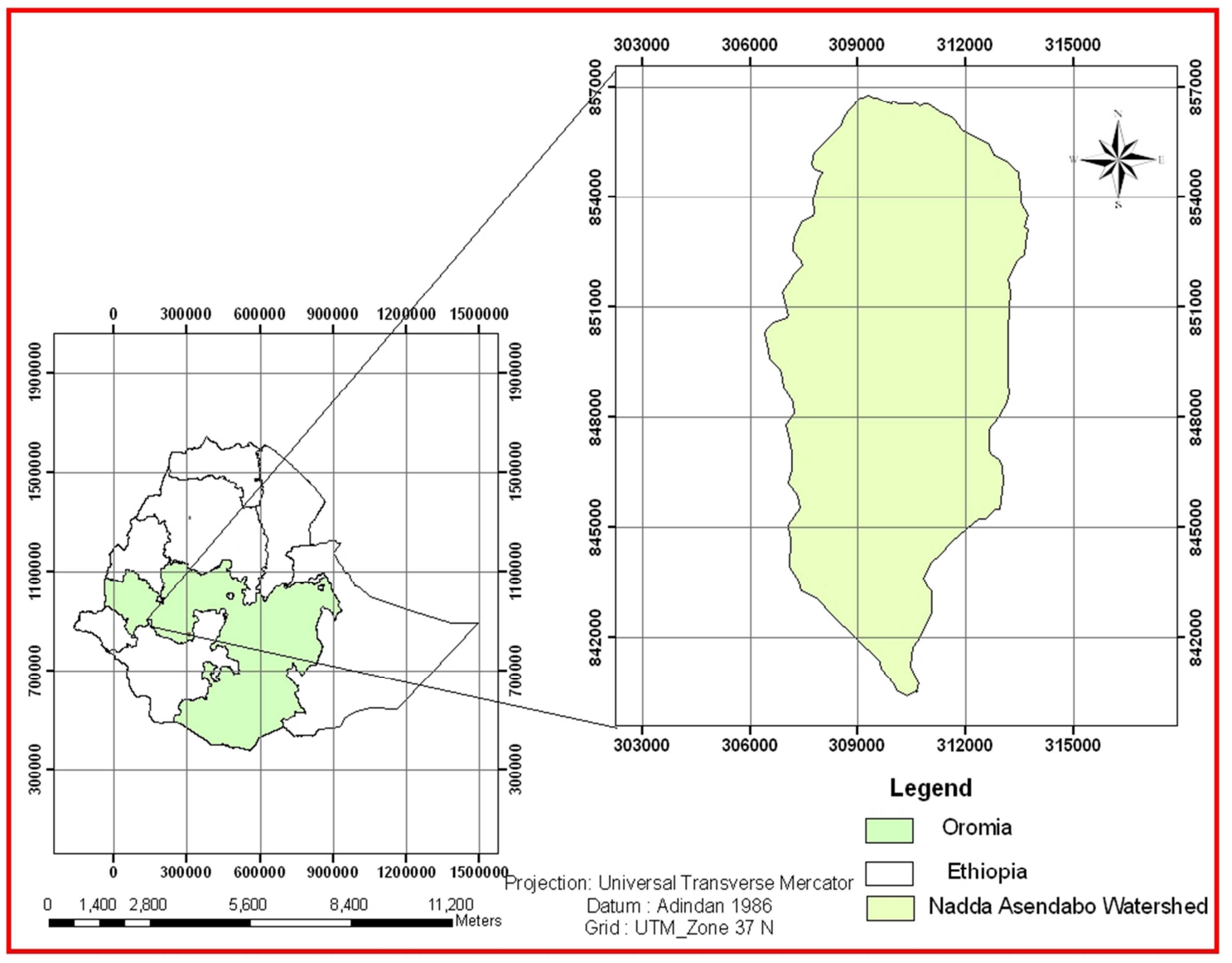

Figure 1. Location map of the study area. 


\section{Materials and Methods}

\subsection{Description of the Study Area}

Nadda Asandabo watershed is located in Omo Nada Woreda, Jimma zone of Oromia Regional State. It is located close to Gilgel Gibe dam-I at about $260 \mathrm{~km}$ South West of Addis Ababa. Geographically it is located between $7^{0} 36^{\prime} 00.87^{\prime \prime}-7^{0} 41^{\prime} 05.72$ " N latitude and $37^{0} 16^{\prime} 55.88^{\prime \prime}$ - $37^{0} 14$ ' 40.73 " E longitude. It covers an area of 8,012 ha. This study was mainly focused on four kebels; Doyo yaya, Biso Gombo, Goro seden, Guddeta bula. The area is characterized by gentle, flat and undulating topography with the altitude ranging from 1650 - $2200 \mathrm{~m}$ a.s.l. According to Van Ranst et al., (2010), the major reference soil groups in the Gilgel Gibe catchment are Nitisols, Acrisols, Ferralsols, Vertisols and Planosols. All these soils have a significant clay $\mathrm{Bt}$ level of dark reddish brown colour. They generally come from the alteration of the basaltic basement and are found on the hills and ridges. According to the surrounding elder's descriptions, 50 years ago the area was covered by indigenous trees such as Poducarpus and Juniperus spps. A later agricultural land expansion has resulted in destruction of forest trees and treats to wildlife (SLMP, 2009).

\subsection{Methodology}

This study was carried out immediately after cropping season specifically for soil sampling from the field in autumn and winter of 2013/2014. This was because of fall is the ideal time of a year to routine soil sampling of crop land. Additionally, cover crops were collected so that humidity standardized for surrounding environment. Furthermore, at this time soil and organic material were separable.

\subsubsection{Experimental Design and Soil Sampling}

Randomized complete block design with split-plot factorial conducted for soil moisture, bulk density and porosity whereas split-split plots for the left soil fertility parameters. The main plots, subplot and sub subplot were slope ranges, land uses and soil depth respectively. However, split plots arrangement was followed for surface soil moisture, bulk density and porosity. Prior to soil sampling, the landscape was divided into three gradients using GPS and clinometers namely; lower (0-15\%), middle $(15-25 \%)$ and upper slopes $(\geq 25 \%)$ followed by selection of three land use types (i.e crop land, grazing land and woodlot) from each gradient. Each treatment was then replicated three times and the soil samples were collected from the depth of $0-20$ and $20-40 \mathrm{~cm}$ using auger. Five samples (in zigzag pattern) were collected to form composite soil samples (54), which were transported to the laboratory for further processing. Plant roots and shoots were handpicked and discarded. Then soil samples were air dried, mixed well before analyses.

\subsubsection{Procedures for Soil Laboratory Analysis}

\section{(i). Soil Physical Properties}

Soil moisture at the sampling time was determined by oven dried at $105^{\circ} \mathrm{c}$ for $24 \mathrm{hrs}$. Then it was expressed by weight as the ratio of the mass of water present to the dry weight of the soil sample as described in Gravimetric method and bulk density was determined by core method (Blake, 1965) after drying a defined volume of soil in an oven at $105{ }^{\circ} \mathrm{C}$ for 24 hours. Finally, soil pore space was calculated from measured bulk density values using the following equation:

Soil porosity $(\mathrm{PS})=1-\frac{D b}{D p}$ whereas, $\mathrm{Db}=$ Bulk density; $\mathrm{Dp}=$ Particle density

For soil texture, initially the soil sample was pretreated with $\mathrm{H}_{2} \mathrm{O}_{2}(30 \%)$ to remove any organic material and sodium hexametaphosphate to disperse complex $\mathrm{Ca}^{++}, \mathrm{Al}^{3+}, \mathrm{Fe}^{3+}$, and other cations that bind clay and silt particles into aggregates. The density of the soil suspension was determined with a hydrometer method (Day, 1965) to read in grams of solids per liter after the sand settles out and again after the silt settles. A correction was made for the density and temperature of the dispersing solution. Percentage of particle size classes were identified according to the USDA textural triangle.

\section{(ii). Soil Chemical Properties}

The $\mathrm{pH}$ was measured in $\mathrm{H}_{2} \mathrm{O}$, in ratio of soil to water (1:2.5), using pH meter whereas Ec measured by conductivity meter using suspension of 1:5 soil: water ratio. Organic carbon was determined by following Walkley and Black method (1934). Then, percent soil organic matter was calculated by multiplying the percent organic carbon by a factor of 1.724. Total Nitrogen (TN) was determined by the micro-Kjeldahl digestion, distillation and titration method (Bremmer and Mulvane, 1982). Available phosphorus (AP) was determined using the standard Bray II. Cation exchange capacity was determined at soil $\mathrm{pH}$ level of 7 after displacement by using $1 \mathrm{~N}$ ammonium acetate method in which it was, thereafter, estimated titrimetrically by distillation of ammonium that was displaced by sodium (Chapman, 1965). Total exchangeable bases were determined after leaching the soils with ammonium acetate (Thomas, 1990). Amounts of $\mathrm{Ca}^{2+}$ and $\mathrm{Mg}^{2+}$ in the leachate were analyzed by EDTA and $\mathrm{K}^{+}$and $\mathrm{Na}^{+}$were analyzed using flame photometrically. Percent base saturation was calculated by dividing the sum of the base forming cations ( $\mathrm{Ca}, \mathrm{Mg}, \mathrm{Na}$ and $\mathrm{K}$ ) by the $\mathrm{CEC}$ of the soil and multiplying by 100 .

\subsubsection{Biomass and Grain Yields Assessment}

Three crop lands (Maize (Zea mays), Teff (Eragrostis tef) and Sorghum (Sorghum bicolor)) were selected for this study since they are commonly practiced in the watershed. These lands and varieties were selected following discussion with farmers, elders and experts. A plot of $2 \mathrm{~m} \times 2 \mathrm{~m}$ was 
temporary established using randomized complete block design with split plot factorial arrangement from the whole selected crop land considering its representativeness. Then for increasing precision of observation each crop land were replicated five times in anticipated ranges of elevation. Finally, the above ground biomass and yield was measured using spring balance in unit of $\mathrm{kg}$ after all grain yield was converted to $\mathrm{kg} / \mathrm{ha}$ and biomass to $\mathrm{t} / \mathrm{ha}$ for result presentation.

\subsection{Statistical Analysis}

Prior to statistical analysis treatments were arranged in factorial randomized complete block design format with slope steepness, land use and soil depth as factors. Three way analysis of variance (ANOVA) was performed to assess the significance of differences in soil parameters between slope steepness, land uses and soil depth, using the general linear model (GLM) procedure of the statistical analysis system (SAS Institute, 1996). A post hoc separation of means was done by LSD test after main effects were found significant at $\mathrm{P}<0.05$.

\section{Results and Discussion}

\subsection{Soil Physical and Chemical Properties Along the Toposequence}

\subsubsection{Surface Soil Bulk Density, Moisture Contents and Porosity}

The maximum mean of soil moisture content at the sampling time was observed in woodlot, whereas the minimum in crop land. Therefore, interaction effect of slope and land use significantly affected $(\mathrm{P} \leq 0.01)$ response of soil moisture and its mean comparison was significantly different $(\mathrm{P} \leq 0.05)$ in crop land at the middle slope, crop and grazing land at the upper slope (Table 1). Woodlot had high leaf cover while others land uses had little leaf cover. This can result in the larger differences in infiltration rate, drainage and evapotranspiration between different land uses. In addition, this was due to the flow of water is low at the lower slope as there is no elevation differences and, thus, it gets time to infiltrate. It is agrees with the findings of Yang (2001). On other hand, the highest mean of soil porosity in woodlot might be come from high organic matter and finer soil particle in this land use type (Table 1 and 2).

Therefore, interaction effect of slope, land uses and soil depths significantly affected $(\mathrm{P} \leq 0.01)$ bulk density and its mean comparison was significantly different $(\mathrm{P} \leq 0.05)$ for all cases except in crop land at the middle slope, grazing land and woodlot at the upper slope (Table 1). Furthermore, soil total porosity affected by these interaction effect in grazing land and woodlot at the lower slope and crop land at the upper slope $(\mathrm{P} \leq 0.01)$ (Table 1$)$.
Table 1. Interaction effects of slope and land use on soil $M C, B D$ and porosity.

\begin{tabular}{lllll}
\hline Slope (\%) & Land use & MC & BD & Porosity \\
\hline \multirow{3}{*}{$0-15$} & CL & $29.75 \mathrm{c}$ & $1.15 \mathrm{f}$ & $56.6 \mathrm{c}$ \\
& GL & $42.11 \mathrm{~b}$ & $1.06 \mathrm{~g}$ & $60 \mathrm{~b}$ \\
& Wl & $56.68 \mathrm{a}$ & $0.94 \mathrm{~h}$ & $71.09 \mathrm{a}$ \\
$15-25$ & CL & $22.35 \mathrm{e}$ & $1.52 \mathrm{c}$ & $40.18 \mathrm{f}$ \\
& GL & $28.35 \mathrm{~d}$ & $1.35 \mathrm{~d}$ & $48.89 \mathrm{e}$ \\
& Wl & $39.96 \mathrm{~b}$ & $1.21 \mathrm{e}$ & $55.27 \mathrm{dc}$ \\
$\geq 25$ & CL & $17.37 \mathrm{~g}$ & $1.74 \mathrm{a}$ & $29.95 \mathrm{~g}$ \\
& GL & $20.72 \mathrm{f}$ & $1.55 \mathrm{bc}$ & $40.16 \mathrm{f}$ \\
LSD (0.05) & Wl & $29.2 \mathrm{~cd}$ & $1.59 \mathrm{~b}$ & $46.31 \mathrm{e}$ \\
CV (\%) & & 1.21 & 0.05 & 4.8 \\
\hline
\end{tabular}

$\mathrm{GL}=$ grazing land, $\mathrm{CL}=$ crop land, $\mathrm{Wl}=$ woodlot, $\mathrm{MC}=$ soil moisture content $\mathrm{BD}=$ bulk density; Means within a column followed by same letters in superscripts are not significantly different from each other at $\mathrm{P}=0.05$.

Table 2. Interaction effects of slope, land use and soil depth on soil particle.

\begin{tabular}{|c|c|c|c|c|c|}
\hline Slope (\%) & LUT & Soil Depth & Sand & Silt & clay \\
\hline \multirow{6}{*}{$0-15$} & \multirow{2}{*}{$\mathrm{Cl}$} & $0-20$ & $13.37 \mathrm{~m}$ & $45.3 \mathrm{a}$ & $41.33 f$ \\
\hline & & $20-40$ & $11.7 \mathrm{o}$ & $39.3 d$ & $49 c$ \\
\hline & \multirow{2}{*}{ Gl } & $0-20$ & 15.161 & $41.17 \mathrm{c}$ & $43.67 \mathrm{ed}$ \\
\hline & & $20-40$ & $14.67 \mathrm{~m}$ & 261 & $59.33 \mathrm{a}$ \\
\hline & \multirow{2}{*}{ Wl } & $0-20$ & $10.33 p$ & $39.3 d$ & $50.37 b$ \\
\hline & & $20-40$ & $15.67 \mathrm{k}$ & $24.33 \mathrm{~m}$ & $60 \mathrm{a}$ \\
\hline \multirow{6}{*}{$15-15$} & \multirow{2}{*}{$\mathrm{Cl}$} & $0-20$ & $28 \mathrm{e}$ & $41 c$ & $31 \mathrm{j}$ \\
\hline & & $20-40$ & $13 n$ & $42.33 b$ & 44.67ed \\
\hline & \multirow{2}{*}{ Gl } & $0-20$ & $28.34 d$ & $36.33 f$ & $35.33 \mathrm{~h}$ \\
\hline & & $20-40$ & $19 \mathrm{j}$ & $37.33 \mathrm{e}$ & 43.67ed \\
\hline & \multirow{2}{*}{ Wl } & $0-20$ & $28.67 \mathrm{c}$ & $27 \mathrm{k}$ & $44.33 \mathrm{ed}$ \\
\hline & & $20-40$ & $24.67 \mathrm{i}$ & $30 \mathrm{i}$ & $45.33 d$ \\
\hline \multirow{6}{*}{$\geq 25$} & \multirow{2}{*}{$\mathrm{Cl}$} & $0-20$ & $39.36 \mathrm{a}$ & $31.96 \mathrm{~h}$ & $28.68 \mathrm{k}$ \\
\hline & & $20-40$ & $27 f$ & $35.33 \mathrm{~g}$ & $37.67 \mathrm{~g}$ \\
\hline & \multirow{2}{*}{ Gl } & $0-20$ & $26.67 \mathrm{~g}$ & $29.33 \mathrm{j}$ & $33.75 \mathrm{i}$ \\
\hline & & $20-40$ & $27 f$ & $37.67 \mathrm{e}$ & $35.33 \mathrm{~h}$ \\
\hline & \multirow{2}{*}{ Wl } & $0-20$ & $35.67 b$ & 25.671 & $38.66 \mathrm{~g}$ \\
\hline & & $20-40$ & $26 \mathrm{~h}$ & $32.33 \mathrm{~h}$ & $41.67 f$ \\
\hline $\operatorname{LSD}(0.05)$ & & & 0.24 & 0.41 & 1.02 \\
\hline CV $(\%)$ & & & 11.32 & 9.45 & 3.28 \\
\hline
\end{tabular}

Means within a column followed by same letters in superscripts are not significantly different

\subsubsection{Soil Particle Distribution Along the Toposequence}

Table 2 clearly shows that sand, silt and clay fractions differed significantly along three slopes, land use types and both soil depths $(\mathrm{P} \leq 0.01)$. Similarly, the sand and clay fraction strongly influenced by interaction effect of slope steepness, land use types and soil depth $(\mathrm{P} \leq 0.01)$ (Table 2$)$. As a result, mean comparison of sand soil particle in woodlot at the lower slope (surface soil), crop land and grazing land (subsurface soil ) at middle slope, crop land (surface), grazing land for both depths and woodlot (subsurface) at the upper slope was significantly different $(\mathrm{P} \leq 0.05)$. The values of silt/clay ratios were $0.63,0.68$ and 0.72 for crop land, grazing land and woodlot soils respectively (Table 2). The decreasing clay content can be used as an indicator for reducing degree of weathering. This finding agrees with the works of Van wambeke (1962) who used silt to clay ratio to estimate the degree of weathering of soil pedon, and postulate that the lower the ratio, the higher the degree of weathering. By increasing weathering, the silt fraction 
changed into clay fraction so that clay content increased, thus the silt/clay ratio was to be lower. Furthermore, results of this study were showed that the ratio of clay contents in soil particle distribution for all land uses increased from surface to sub-surface along the gradient. This result agree with the works of Ashanafi et al. (2010); Esteban et al. (2000) and Sheleme (2011) who reported that the texture of the subsurface horizons became finer with soil depth, due to migration of clay from surface to lower horizons.

Silt fraction affected significantly by interaction of land use and soil depth $(\mathrm{P} \leq 0.05)$, slope and land use and slope and soil depth $(\mathrm{P} \leq 0.01)$ (Table 2$)$ but mean comparison in grazing land and woodlot, surface and subsurface soil depth was not significantly different. In addition, clay fraction in crop land (surface soil), grazing land and woodlot (subsurface soil) at the lower slope, crop and grazing land (surface soil) at the middle slope as well as all land uses at the upper slope was significantly different $(\mathrm{P} \leq 0.05)$. This result agreed with the findings of Van wambeke (1962).

In addition it was supported by the works of (Ogeh and Ukodo, 2012) which revealed that sand fraction generally dominated the soils along the toposequence. Within the horizons, the sand content decreased with depth in all the profiles, silt content increased with depth in all the profile.

\subsubsection{Soil pH, EC, SOM, TN and AP, Exchangeable Bases, $B S$ and $C E C$}

Results of the present studies showed that soil $\mathrm{pH}$ increased down slope and with soil depth (Table 3). Statistically, $\mathrm{pH}$ was significantly affected by interaction of slope steepness, land use and soil depth in crop land, grazing land and woodlot (subsurface soil) grazing land (surface soil) at the upper slope (Table 3). Relatively lower $\mathrm{pH}$ values in the soil of the crop fields and grazing land, as compared to those under woodlot, might be due to depletion of basic cations by the harvested crop biomass, over grazing and leaching. Gebeyaw (2007) has also reported that a lower $\mathrm{pH}$ value in cultivated land was attributed to a high rate of organic matter oxidation. This is important to produce organic acids and provide $\mathrm{H}^{+}$to the soil solution, and thereby reduces soil $\mathrm{pH}$ values. This explanation was also partially supported by Tana (1996) and Butros et al. (2010) who reported that soil $\mathrm{pH}$ was increased with soil depth along the gradient due to carbonate content of the soil and high intensity of rain fall.

Table 3. Interaction effects of slope, land use and soil depth on soil physico-chemical properties.

\begin{tabular}{|c|c|c|c|c|c|c|c|c|c|c|c|c|c|}
\hline \multirow{2}{*}{$\begin{array}{l}\text { Slope } \\
(\%)\end{array}$} & \multirow{2}{*}{$\begin{array}{l}\text { Land } \\
\text { use }\end{array}$} & \multirow{2}{*}{$\begin{array}{l}\text { Soil depth } \\
(\mathrm{cm})\end{array}$} & \multirow{2}{*}{ pH } & \multirow{2}{*}{ Ec (dS-1m) } & \multirow{2}{*}{ OM(\%) } & \multirow{2}{*}{ TN (\%) } & \multirow{2}{*}{$\mathbf{A P}(\mathbf{p p m})$} & $\mathbf{C a}$ & Mg & $\mathbf{N a}$ & $\mathbf{K}$ & CEC & \multirow{2}{*}{ BSP $(\%)$} \\
\hline & & & & & & & & \multicolumn{5}{|c|}{ cmol+Kg- of soil } & \\
\hline \multirow{6}{*}{$0-15$} & \multirow{2}{*}{$\mathrm{Cl}$} & $0-20$ & $6.51 \mathrm{f}$ & $0.042 \mathrm{fgh}$ & $6.25 \mathrm{cbd}$ & $0.39 \mathrm{ed}$ & $4.56 \mathrm{efg}$ & $12.61 \mathrm{jik}$ & $5.04 \mathrm{de}$ & $0.34 \mathrm{fg}$ & $0.56 \mathrm{eghf}$ & $25.33 \mathrm{f}$ & $72.94 \mathrm{fe}$ \\
\hline & & $20-40$ & $6.6 \mathrm{e}$ & $0.05 \mathrm{ef}$ & 5.47 cebd & 0.32 fheg & $4.14 \mathrm{~g}$ & $16.07 \mathrm{ef}$ & $5.67 \mathrm{dc}$ & $0.44 \mathrm{de}$ & $0.69 \mathrm{ed}$ & $34.67 \mathrm{c}$ & $66.57 \mathrm{ijk}$ \\
\hline & \multirow{2}{*}{ Gl } & $0-20$ & $6.78 \mathrm{~d}$ & $0.066 \mathrm{~d}$ & $8.98 \mathrm{a}$ & $0.49 \mathrm{cb}$ & $7.61 \mathrm{a}$ & $16.93 \mathrm{ecd}$ & $6.6 \mathrm{c}$ & $0.52 \mathrm{dc}$ & $0.75 \mathrm{~cd}$ & $33.44 \mathrm{dc}$ & 74.74dce \\
\hline & & $20-40$ & $6.85 \mathrm{c}$ & $0.079 \mathrm{c}$ & $6.87 \mathrm{~b}$ & $0.4 \mathrm{ced}$ & $6.28 \mathrm{~b}$ & $18.4 \mathrm{bcd}$ & $8.96 b$ & $0.64 \mathrm{ba}$ & $0.92 \mathrm{cb}$ & $42.18 b$ & 68.67hgi \\
\hline & \multirow{2}{*}{ W1 } & $0-20$ & $6.91 \mathrm{~b}$ & $0.204 b$ & $9.63 \mathrm{a}$ & $0.65 \mathrm{a}$ & $5.29 \mathrm{~cd}$ & $19.9 \mathrm{~b}$ & $9.39 \mathrm{~b}$ & $0.61 b$ & $0.89 \mathrm{cb}$ & $42.29 b$ & $73.16 \mathrm{fe}$ \\
\hline & & $20-40$ & $6.98 \mathrm{a}$ & $0.355 \mathrm{a}$ & $8.86 \mathrm{a}$ & $0.5 b$ & $4.73 \mathrm{defg}$ & $21.31 \mathrm{a}$ & $12.23 \mathrm{a}$ & $0.71 \mathrm{a}$ & $1.75 \mathrm{a}$ & $47.09 \mathrm{a}$ & $76.81 b c$ \\
\hline \multirow{5}{*}{$15-25$} & $\mathrm{Cl}$ & $20-40$ & $5.87 \mathrm{j}$ & $0.028 \mathrm{ijk}$ & $4.83 \mathrm{efd}$ & 0.29 fhig & $2.37 \mathrm{hij}$ & $14.23 \mathrm{ihfg}$ & $4.13 \mathrm{fe}$ & $0.3 \mathrm{hg}$ & $0.51 \mathrm{ghf}$ & $25.05 f$ & $77.44 \mathrm{bc}$ \\
\hline & \multirow{2}{*}{ Gl } & $0-20$ & $5.73 \mathrm{k}$ & $0.037 \mathrm{ghi}$ & 5.79cebd & 0.33 feg & $4.92 \mathrm{def}$ & 14.15jihfg & $5.27 \mathrm{dce}$ & $0.34 \mathrm{fg}$ & $0.55 \mathrm{eghf}$ & $25.93 \mathrm{fe}$ & $78.79 b$ \\
\hline & & $20-40$ & $5.93 \mathrm{i}$ & $0.046 f g$ & $6.45 \mathrm{cb}$ & 0.29fhig & $5.89 b c$ & $15.54 \mathrm{efg}$ & $5.82 \mathrm{dc}$ & $0.48 \mathrm{de}$ & $0.64 \mathrm{egdf}$ & $30.28 \mathrm{de}$ & 74.67 dce \\
\hline & \multirow{2}{*}{ Wl } & $0-20$ & $6.2 \mathrm{~h}$ & $0.046 \mathrm{fg}$ & 5.81cebd & $0.37 \mathrm{fe}$ & $4.17 \mathrm{~g}$ & $16.8 \mathrm{ed}$ & $6.18 \mathrm{dc}$ & $0.44 \mathrm{de}$ & $0.68 \mathrm{edf}$ & $33.3 \mathrm{dc}$ & 71.68 feg \\
\hline & & $20-40$ & $6.28 \mathrm{~g}$ & $0.061 \mathrm{de}$ & $6.59 \mathrm{~b}$ & $0.47 \mathrm{cbd}$ & $4.9 \mathrm{def}$ & $19.04 b c$ & $8.7 b$ & $0.58 \mathrm{bc}$ & $1.01 \mathrm{~b}$ & $39.39 b$ & 74.46 dce \\
\hline \multirow{5}{*}{$\geq 25$} & \multirow{2}{*}{$\mathrm{Cl}$} & $0-20$ & $5 s$ & 0.0141 & $2.59 \mathrm{~g}$ & $0.13 \mathrm{j}$ & 2.3hij & $7.41 \mathrm{k}$ & $2.49 \mathrm{~g}$ & $0.14 \mathrm{j}$ & $0.18 \mathrm{j}$ & $16.57 \mathrm{~h}$ & $61.68 \mathrm{~m}$ \\
\hline & & $20-40$ & $5.13 r$ & $0.019 \mathrm{kl}$ & $3.29 \mathrm{gf}$ & $0.21 \mathrm{ji}$ & $1.45 \mathrm{jk}$ & $9.93 \mathrm{jk}$ & $1.82 \mathrm{~g}$ & $0.18 \mathrm{ji}$ & $0.26 \mathrm{ij}$ & $18.45 \mathrm{~g}$ & 66.10 \\
\hline & Gl & $20-40$ & $5.23 \mathrm{np}$ & $0.035 \mathrm{ghij}$ & $4.54 \mathrm{ef}$ & $0.27 \mathrm{hig}$ & $3.26 \mathrm{~h}$ & 14.14jihfg & $4.27 \mathrm{fe}$ & $0.33 \mathrm{fg}$ & $0.38 \mathrm{ih}$ & $26.03 \mathrm{fe}$ & $73.591 \mathrm{k}$ \\
\hline & \multirow{2}{*}{ Wl } & $0-20$ & $5.2 \mathrm{opq}$ & $0.037 \mathrm{ghi}$ & $4.67 \mathrm{ef}$ & $0.26 \mathrm{hig}$ & 2.57hij & $14.96 \mathrm{ehfg}$ & $5.09 \mathrm{de}$ & $0.28 \mathrm{hg}$ & $0.39 \mathrm{ih}$ & $29.67 f$ & $69.85 n$ \\
\hline & & $20-40$ & $5.4 \mathrm{~m}$ & $0.043 \mathrm{fg}$ & $4.94 \mathrm{ced}$ & 0.29 fhig & $2.82 \mathrm{hi}$ & $15.89 \mathrm{ef}$ & $6.02 \mathrm{dc}$ & $0.4 \mathrm{fe}$ & $0.48 \mathrm{gh}$ & $34.3 \mathrm{dc}$ & $66.64 \mathrm{ij}$ \\
\hline \multirow{2}{*}{\multicolumn{2}{|c|}{$\begin{array}{l}\operatorname{LSD}(0.05) \\
\operatorname{CV}(\%)\end{array}$}} & & 0.05 & 0.011 & 1.56 & 0.09 & 0.68 & 2.22 & 1.36 & 0.08 & 0.18 & 4.37 & 3.04 \\
\hline & & & 3.1 & 8.1 & 13.82 & 10.95 & 13.55 & 6.02 & 13.75 & 8.83 & 14.77 & 4.86 & 7.56 \\
\hline
\end{tabular}

Land use are the same as Table 3; BSP= Base Saturation Percentage; Means within a column followed by same letters in superscripts are not significantly different from each other at $\mathrm{P}=0.05$

Interaction effect of slope and land use on Ec was significantly different in grazing land (surface) and woodlot (surface and subsurface) at the lower slope comparatively with others $(\mathrm{P} \leq 0.05)$ (Table 3$)$. Following this scenario, Ec were higher in the woodlot with a mean of $0.355 \mathrm{dS}^{-1} \mathrm{~m}$, whereas the lowest $0.014 \mathrm{dS}^{-1} \mathrm{~m}$ in the crop land at the upper slope (Table 3). Generally, Ec increased from surface to subsurface for all land uses, following sequential landscape gradients (Table 3). This result was in agreement with the findings of Doerge et al. (1999) and Butros et al. (2010) indicating greater clay particle percentage, loss of Calcium
(Ca), Magnesium (Mg), Sodium ( $\mathrm{Na}$ ) and Potassium (K) containing soluble salts after deforestation and cultivation and increased porosity of the soil under these land uses resulted in reduction of soil electrical conductivity. This result also supported by the works of (Alemayehu and Sheleme, 2013) which indicated crop with high biomass and large physiological activities assists soil erodibility.

SOM in crop land at the lower slope was significantly different $(\mathrm{P} \leq 0.05)$ from middle and upper slope due to interaction effects of slope with land use and soil depth (Table 3). The lower organic matter observed in crop and 
grazing land comparing to woodlot could be explained by the seasonal cover in the former following over cultivation, free grazing and absence of soil nutrient balance. Removal of the surface soil rich in organic matter by soil erosion which undoubtedly could have accelerated with the removal of the plant cover is also expected to contribute to the lower organic matter contents observed in the crop and grazing land. The maintenance high levels of organic matter under woodlot are apparently attributed to the presence of vegetation and the associated high biomass and litter fall in the soils. This result was in agreement with the works of (Pan and Bhardwaj, 2013) forest has the highest carbon pool where as the agricultural crop had the lowest carbon pools in comparison.

Soil TN in woodlot at the lower slope (surface and subsurface) was significantly different $(\mathrm{P} \leq 0.05)$ from other land use type at the three slopes due to interaction of these factors (Table 3). In line with soil organic matter contents, the highest mean soil total nitrogen $(0.65 \%)$ was observed in the woodlot followed by the grazing land $(0.5 \%)$, where as the lowest value $(0.13 \%)$ of total nitrogen was recorded in the crop lands (Table 3). Reduced input of plant residues into the soils also has contributed to the depletion of organic matter thereby enhanced rate of nitrogen in crop land. As the area receiving high mean annual rain fall, leaching could be another reason for the decline in $\mathrm{TN}$ in cropped fields. Nitrate ions which are not adsorbed by the negatively charged colloids dominate in most soils and, thus, move downward with drainage water and are readily leached from the soil. Removal of crop residues and subsistence agricultural system affects nutrient balance more negatively (Fitsum et al., 1999).

AP was significantly different $(\mathrm{P} \leq 0.05)$ in grazing land (surface) at lower slope comparatively with land use in all slope along a toposequence due to interaction effects of slope, land use and soil depth. Reduction of AP contents could be related to degree of its fixation which occurs at low $\mathrm{pH}$ levels where iron and aluminum activity actually increases (Brady and Weil, 2002). According to the reports of Maja (2011) for health vegetation, increase in elevation was associated with a decrease in soil $\mathrm{NH}_{4}^{+}$and $\mathrm{PO}^{3-}$ concentrations because the soil fungal: bacterial ratio was lowest at the lower elevations.

Exchangeable cations, $\mathrm{Ca}, \mathrm{Mg}, \mathrm{Na}$ and $\mathrm{K}$ were significantly different $(\mathrm{P} \leq 0.05)$ in woodlot (subsurface) at the lower slope due to interaction effects of slope, land use and soil depths (Table 3). This finding agreed with (Maja, 2011) reports, less amounts of soil erosion by water and high resistance of cations from leaching at foot slope and area covered by perennial vegetations improved level of exchangeable cations in the soil.

Cation exchange capacity was greater in woodlot land use type and at the lower slope (Table 3). This results supported by (Brady and Weil, 2002) cation exchange capacity increased with the ability of plant root to anchor soil mass and not rugged landscape which is less vulnerable to landslide due to elevation differences. Thus, this study was revealed that interaction effects of slope, land uses and soil depths along a toposequence was indicated CEC was significantly different $(\mathrm{P} \leq 0.05)$ in woodlot (subsurface) at the lower and middle slope from other values observed (Table 3)

Observed base saturation percentage in crop land at middle (surface) and upper (subsurface) slope was significantly different $(\mathrm{P} \leq 0.05)$ from others due to interaction effects of slope steepness, land use and soil depth (Table 3 ). This result was agreed with findings of Hikmatullah et al. (2003).

\subsection{Crop Biomass and Grain Yield Along the Toposequence}

Productivity of above ground biomass for sorghum and maize at the lower slope and teff at the upper slope was significantly different $(\mathrm{P} \leq 0.01)$ from others due to the interaction effects of slope and crop type along the toposequences. Mean grain yields were ranged from 495$1070 \mathrm{~kg}$ (teff), 1890-5500 kg (maize), 2235-2360 kg (sorghum) along the landscape. This result was significantly different $(\mathrm{P} \leq 0.05)$ in grain yield obtained from maize at all slope and teff yields at upper slope due to interaction effects of slope and crop type. It was agreed with works of Grabherr, 2009, as cited in Fabien, 2012).

Table 4. Interaction effects of slope and crop type on biomass and grain yields.

\begin{tabular}{llll}
\hline Slope (\%) & Crop type & Biomass & Grain yield \\
\hline \multirow{3}{*}{$0-15$} & sorghum & $32.95 \mathrm{a}$ & $2250 \mathrm{c}$ \\
& Teff & $10.62 \mathrm{f}$ & $1070 \mathrm{e}$ \\
& Maize & $25.19 \mathrm{~b}$ & $5500 \mathrm{a}$ \\
$15-25$ & sorghum & $19.99 \mathrm{c}$ & $2235 \mathrm{c}$ \\
& Teff & $6.55 \mathrm{~g}$ & $895 \mathrm{f}$ \\
& Maize & $19.27 \mathrm{dc}$ & $3465 \mathrm{~b}$ \\
$\geq 25$ & sorghum & $13.7 \mathrm{ef}$ & $2360 \mathrm{c}$ \\
& Teff & $4.16 \mathrm{~g}$ & $495 \mathrm{~g}$ \\
LSD (0.05) & Maize & $11.67 \mathrm{ef}$ & $1890 \mathrm{~d}$ \\
CV (\%) & & 3.71 & 139 \\
\hline
\end{tabular}

Means within a column followed by same letters in superscripts are not significantly different

\section{Conclusion and Recommendations}

Based on this study results, most of soil nutrients significantly decreased due to soil erosion and landscape features with increasing slope steepness and unwise utilization of land. Thus higher organic matter, cation exchange capacity, soil moisture, finer soil particle, basic cation, nitrogen and phosphorus observed at foot slope and woodlot land use type. So that soil and water conservation measures like hillside trench, terracing, micro and macro basin should layout at the upper watershed side according to its suitability in the watershed. Therefore, lower slope watershed community should work cooperatively with upper and middle watershed since household in the lower watershed benefited from offsite nutrient movement to their 
lands. This will be happened according to this research output through allocating woodlot land use type between fragmented crops and grazing land and empowering local community through training on how they can prepare organic fertilizer from locally available materials.

\section{References}

[1] Abebayehu, A. 2010. Soil Fertility Management and Nutrient Balance in Farm Components and Socioeconomic Groups: A Case Study in Selected Sites of Gilgel Gibe Catchment. MSc Thesis, Hawassa University, Ethiopia.

[2] Alemayehu Kiflu and Sheleme Beyene, 2013. Effects of different land use systems on selected soil properties in South Ethiopia. Journal of soil science and Environmental Management. Vol.4(5), pp. 100-107.

[3] Amanuel Abate, 2011. Land Use Dynamics and Its Impact on Productivity. MSc. Thesis, Jimma University, Ethiopia. analysis. Agron. Part I, No. 9, Am. Soc. Agron. Madison, Wisconsin, USA.

[4] Ashanafi Ali, Abaynesh Esayas and Sheleme Beyene, 2010. Characterizing Soils of Delbo Wegene Watershed, Wolaita Zone, and Southwestern Ethiopia for Planning Appropriate Land Management. Journal of Soil Science and Environmental Management Vol.1 (8), pp.184-199.

[5] Azene, B., 1997. A Participatory agro-forestry approach for soil and water conservation in Ethiopia. PhD Dissertation, Wageningen Agricultural University, The Netherland.

[6] Blake, G. R., 1965. Bulk density. pp. 374-399. In: C. A. Black (ed.). Methods of soil

[7] Brady, N. C. and Weil, R. R., 2002. The nature and properties of soils. 13th ed. Prentice Hall Inc., New Jersey. 960p.

[8] Brady, N. C. and Weil, R. R., 2002. The nature and properties of soils. 13th ed. Prentice Hall Inc., New Jersey. 960p.

[9] Bremner, J. M. and Mulvaney, C. S. 1982. "Total nitrogen”, In: A. L. Page, R. H. Miller and D. R. Keeny, (Eds.), Methods of Soil Analysis, American Society of Agronomy and Soil Science Society of America, Madison, pp. 1119-1123.

[10] Brubaker, S. C., Jones, A. J., Lewis, D. T. and Frank, K., 1993. Soil Properties associated with landscape positions. Soil Sci. Soc. Am. J. 57: 235-239.

[11] Butros, I. H., Awni, Y. Taimeh and Feras, M. Ziadat., 2010. Variation in soil chemical properties along toposequences in an Arid Region of the Levant.Catena 83 (2010) 34-45.

[12] Buytaert, W., J. Deckers, G. Dercon, B. D. Bierve, J. Poesen and G. Govers, 2002. impactof land use changes on the hydrological properties of Volcanic Ash Soils in South Ecuador. Soil Use and Management 18: 94-100.

[13] Buzuayehu, T., Gezahegn, A., Yigezu, A., Jabbar, M. A. and Paulos, D., 2002. Nature and causes of land degradation in the Oromiya Region: A review. Socio-economics and Policy Research Working Paper 36. ILRI (International Livestock Research Institute), Nairobi, Kenya. $82 \mathrm{pp}$. catchment of the Loess Plateau, China

[14] Central Statistical Agency (CSA), 2010. Agricultural sample survey. Statistical Bulletin 468, Octeber, 23-27, CSA, Addis Ababa, Ethiopia.

[15] Central Statistical Agency (CSA), 2010. Agricultural sample survey. Statistical Bulletin 468, Octeber, 23-27, CSA, Addis Ababa, Ethiopia.

[16] Chapman, H. D., 1965. Cation exchange capacity. In: Black et al., C. A. (eds.). Methods of

[17] Chris, J. Grose, Darren, B. Kidd, Robert M. Moreton and Susan, E. Tate., 2004. Quantifying trends in soil condition: gathering baseline data for developing targets and supporting informed land management decision making. Water and Environment, Tasamani.

[18] Day, P. R., 1965. Hydrometer method of particle size analysis. pp. 562-563. In: C. A. Black (eds.). Methods of soil analysis. Agron. Part II, No. 9. Am. Soc. Agron. degradation and restoration in the Highlands of Ethiopia: Implications for sustainable land management. Doctoral thesis. Swedish University of Agricultural Sciences, Uppsala, Sweden. 70p.

[19] Demel, T., 2001. Vegetation type and forest fire management in Ethiopia, pp 1-35. Proceedings of Round-Table Conference on Integrated Forest Fire Management in Ethiopia. September 19-21, 2001, Ministry of Agriculture, Addis Ababa.

[20] Desta, K., 2003. Farmers' perception of crop trend and soil fertility management constraints in the Kabale District, Msc Thesis, Bahir dar University, Ethiopia.

[21] Doerge, T., N. R. Kitchen and E. D. Lund, 1999. Site specific management guidelines. South Dakota State University, USA.

[22] Esteban, G., Jobba Gy and Robert, B. Jackson, 2000. The vertical distribution of soil organic carbon and its relation to climate and vegetation. Ecological Applications, 10(2), 2000, Pp. 423- 436.

[23] Fabien, A. and Oliver, D. 2012. Persipective in Plant Ecology, Evolution and Systematics.

[24] Fitsum Hagos, John Pender and Nega Gebreselasie. (1999). Land Degradation in the Highlands of Tigray and Strategies for Sustainable Land Management. Addis Abeba, Ethiopia.

[25] Gebeyaw, T., 2007. Soil fertility status as influenced by different land uses in

[26] Hikmatullah, H. Subagyo and B. H. Prasetyo, 2003. Soil Properties of the Eastern Toposequence of Mount Kelimutu. Flores Island. East Nusa Tenggara and their Potential for Agricultural Use. Indonesian Journal of Agricultural Science 4(1) 2003: 1-11.

[27] Jimma Zone Agriculture and Rural Development Sector (JZARDS), 2011. Annual Report on sustainable land management strategies, Jimma, Ethiopia.

[28] Maja Sundqvist, 2011. Nitrogen and Phosphorus Dynamics Across an Elevational Gradient in aSwedish Subarctic Tundra. Doctoral Thesis, Swedish University of Agricultural Sciences, Umea.

[29] Maybar areas of south Wello Zone, north Ethiopia. M. Sc. Thesis, Haramaya University, Haramaya, Ethiopia.

[30] Muchena, F. N., 2008. "Indicators for sustainable land management in Kenya's Context". GEF Land Degradation Focal Area Indicators, ETC-East Africa. Nairobi, Kenya. 
[31] Ogeh J. S. and Ukodo E., 2012. Profile Distribution of Physical and Chemical Properties in Soils of a Toposequence in Benin, Rainforest of Nigeria. Nigerian Journal of Basic and Applied Science (March, 2012), 20(1): 68-72.

[32] Pal S., Panwar P., Bhardwaj D. R., 2013. Soil quality under forest compared to other land uses in acid soil of North Western Himalaya, India Ann. For. Res. 56(1):187-198, 2013.

[33] Sheleme, B., 2011. Characterization of Soils along a Toposequence in Gununo Area, Southern Ethiopia. Journal of Science and Development 1(1) 2011, 31-41 soil analysis. Agronomy 9: 891-901. Am. Soc. Agro., Inc., Madison, Wisconsin.

[34] Sustainable land Management Programme (SLMP), 2010. Causes, consequences and solution of land degradation in Omo Nadda District: Annual report by SLMP woreda level. Nadda, Ethiopia.

[35] Taffesse, Alemayehu, S. Dorosh, Paul, A. and Sinafikeh, 2011.
Crop production in Ethiopia Regional Patterns and Trends. International Food Policy Research Institute (IFPRI).

[36] Van Ranst E, Tolossa A R, Dumon M, Cornelis J-T and Deckers J (2010). On the origin of planosols - the process of ferrolysis revisited. 19th World Congress of Soil Science, Soil solutions for a Changing World, Brisbane, Australia.

[37] Van wambeke, A. R., 1962. criteria for classifying tropical soils by age. J. Soil Sci. 13 .

[38] Wischmeier, W. H. and Smith, D. D., 1978. Predicting rainfall erosion losses - a guide to conservation planning. U. S. Agricultural Handbook 537. US Department of Agriculture, Washington, DC, USA. 58 pp.

[39] Wolayita zone, southern Ethiopia. M. Sc. Thesis, Hawassa University, Ethiopia.

[40] Yang Qiu, Bojie Fu, Jun Wang A., Liding Chen, 2001. Spatial variability of soil moisture content and its relation to environmental indices in a semi-arid gully. 